\title{
Serum Haptoglobin Responses following Rumenotomy in the Sahel Goat
}

\author{
Saidu $\mathrm{AM}^{* 1}$, Bokko $\mathrm{PB}^{1}$, Mohammed $\mathrm{A}^{1}$ and Bukbuk $\mathrm{DN}^{2}$
}

${ }^{1}$ Department of Veterinary Surgery and Theriogenology, University of Maiduguri, Maiduguri, Borno State, Nigeria

${ }^{2}$ Department of Microbiology, University of Maiduguri, Maiduguri, Borno State, Nigeria

${ }^{*}$ Corresponding author: Saidu AM, Department of Veterinary Surgery and Theriogenology, University of Maiduguri, Maiduguri, Borno State, Nigeria, E-mail: abubakarsm51@gmail.com

Citation: Saidu AM, Bokko PB, Mohammed A, Bukbuk DN (2016) Serum Haptoglobin Responses following Rumenotomy in the Sahel Goat. J Vet Sci Ani Husb 4(2): 203. doi: 10.15744/2348-9790.4.203

\section{Received Date: February 28, 2016 Accepted Date: May 24, 2016 Published Date: May 26, 2016}

\begin{abstract}
Fifteen Sahel goats were randomly allocated into three groups A, B and C to evaluate Serum Haptoglobin (Hp) profiles following rumenotomy as markers of surgical stress using Quantitative ELISA. Diazepam at $0.2 \mathrm{mg} / \mathrm{kg}$ was administered intravenously to sedate goats in groups $\mathrm{A}$ and $\mathrm{B}$ with subsequent lidocaine $\mathrm{HCl}$ and bupivacaine inverted-L block for groups $\mathrm{A}$ and $\mathrm{B}$ respectively. Group $\mathrm{C}$ did not receive any treatment. Chromic catgut (CCG) and Polyglycolic Acid (PGA) sutures were used for rumen closure and apposition of abdominal muscles for groups A and B respectively while nylon for skin closure. Blood samples were collected via jugular venipuncture before induction of anaesthesia to establish baseline data. Further blood sampling were at five minutes post anaesthetic induction (PAI) and immediately after surgery 0 hour ( $38 \pm 6.0$ minutes post surgery), then subsequently at $5,8,24,48$ and 72 hours post surgery. Values in groups A and B differs significantly $(\mathrm{P}<0.05)$. Group A peak Hp values was $6.23 \pm 1.82 \mathrm{mg} / \mathrm{mL}$ at $72 \mathrm{hrs}$ post surgery. The goats in group B had a peak of $4.26 \pm 1.55 \mathrm{mg} / \mathrm{mL} \mathrm{Hp}$ at $72 \mathrm{hrs}$ post surgery. Hp in the Sahel goat showed no significant stress at five minutes post induction of local anaesthesia with lidocaine and bupivacaine post diazepam sedation. The sutures in the experiment CCG and PGA, produced significant stress but was earlier in onset and highest in concentration among goats that had sutured rumen and abdominal muscles with CCG (group A).
\end{abstract}

Keywords: Goat; Haptoglobin; Rumenotomy; Polyglycolic acid; Chromic catgut; Sutures; Stress

List of abbreviations: CCG: Chromic Catgut; PGA: Polyglycolic Acid; DBC: Diazepam -Bupivacaine Combination: DLC: Diazepam -Lidocaine Combination; HP: Haptoglobin; APP: Acute phase protein

\section{Introduction}

Rumenotomy a surgical incision into the rumen is a routine surgical procedure that is performed to relieve some disease conditions of the rumen and/or fore stomach. Traumatic gastritis, rumen impaction, rumen foreign bodies, hardware disease, acute and recurrent tympani, ingestion of toxic plants, chemicals, spoiled roughages or fetal membrane after parturition, are rumenotomy indications [1-3]. Rumen Skin Clamp Fixation Technique (RSCF) is a fast, all purpose rumenotomy technique that produces a clean wound after rumen closure [2].

Although tissue reactions which might be associated with suture material have rarely been reported in the past [4], suture materials play an important role in postoperative wound healing, eliciting different degrees of reaction after wound closure. Sutures are available as absorbable or non-absorbable and both are either synthetic or natural sutures. Tissue reactions to suture materials used for surgical interventions may vary depending on the surface properties and bacterial adherence properties of the material [4]. It is well known that next to patient-associated and surgeon-related factors, biomaterials or sutures might have an impact on postoperative inflammatory process and healing, these changes or effects are still not fully understood especially on acute phase protein profiling [4]. For clarification, evaluations of the tissue reactions of biomaterials including possible interactions or combined reactions were recommended to be evaluated. A review of tissue reactions to various suture materials used in surgical interventions showed that polyglecaprone- 25 had positive effects on wound-healing as compared to silk. Some studies reported that silk elicits more intense tissue inflammatory response and delayed wound healing as compared to other suture materials including polyglecaprone-25, polyglycolic acid (PGA), and nylon [5]. In chronic implantations, the reaction to various suture materials differs from that observed in the acute stages [4,6] while in one clinical study, Polygalactin 910 sutures were associated with the development of stitch abscess [5]. Several studies reported that tissue reactions are minimal with nylon sutures and this was why nylon was chosen in this study for both experimental groups to evaluate a clearer effect or response of the absorbable sutures [5]. These serious changes in the response to surgical sutures after being buried in the wound bed is yet to be captured on acute phase protein profiling such as $\mathrm{Hp}$, notably looking into how chromic catgut and polyglycolic acid sutures are frequently used in the study area. Diazepam at a dose rate of $0.1-0.25 \mathrm{mg} / \mathrm{kg}$ is used in goats for sedation administered as slow intravenously injection to 
provides 30 minutes of good sedation but without analgesia [7,8]. It is the drug of choice in goats presented for surgeries with cardiovascular or pulmonary diseases [8]. Contrary to general anesthesia (GA) characterized by controlled and reversible unconsciousness and analgesia the local or regional anesthesia refers to loss of sensation in circumscribed body area or insensibility in a larger, though limited, body area such as paralumbar nerve blockade [9]. The most useful regional blocks for these species are the cornual block, inverted L-block, paravertebral, and intravenous regional anesthesia of the limb while including caudal epidural in the cattle [10]. Lidocaine is the most commonly used local anesthetic because it is well tolerated by goats [10]. Clinically bupivacaine is utilized for intraoperative local anesthesia, post-operative analgesia and in the treatment of chronic pain [11]. The major advantages of bupivacaine with particular emphasis on clinical use in surgery compared with other presently used local anesthetics are an increased duration of action and a favorable potency to toxicity ratio.

Haptoglobin (Hp) a plasma a2-glycoprotein is an acute phase reactant in all species with a variety of inflammatory conditions produced primarily by the liver. They are also produced in small amount by the skin, lung and kidney. Hp binds to free haemoglobin $\mathrm{Hb})$ released from red blood cells with high affinity and thereby inhibiting its oxidative activity. The reticulo-endothelial system removes the $\mathrm{Hp}-\mathrm{Hb}$ complex to cause decline in $\mathrm{Hp}$ levels. Free $\mathrm{Hp}$ is released into circulation during intravascular haemolysis that binds $\mathrm{Hb}$. This causes decline in Hp levels. In contrast, extravascular hemolysis the reticuloendothelial system, especially splenic monocytes phagocytose the erythrocytes and $\mathrm{Hb}$ is not released into circulation, serum Hp levels are normal. The main function of $\mathrm{Hp}$ is to bind haemoglobin, thus preventing renal damage and iron loss as well as inhibiting the utilization of iron by pathogenic bacteria [12]. The normal range values for goat HP is $0.39-1.26 \mathrm{mg} / \mathrm{mL}$ but differ markedly by species [13]. An increased serum and plasma level of this protein has been reported following pathologic conditions. Plasma Hp concentration have been reported in the past to cause no significant effect on gender, pregnancy, lactation status, or age of an animal [14] but recently many researchers reported that acute phase proteins including the serum haptoglobin concentration is influenced by age, growth and development in goats and other ruminant animals $[15,16]$. Hp is deemed a major positive acute phase protein in ruminants as its concentration rises more than 10 times in response to the stimulation [17]. It is induced by interleukin 6, secreted by monocytes and inhibits bacterial proliferation by restriction of the availability of free iron [18]. Plasma Hp of bull calves increased significantly following surgical castration [19]. Caprine surgeries are mostly conducted with local anesthesia after premedication with sedatives or tranquilizers such as alpha-2 agonist, benzodiazepines, or phenothiazines and has greatly contributed to improvement of surgical procedures in veterinary practice $[8,20]$. These drugs can modify the physiologic states of the body by acting on the nervous system hence the endocrine or neuroendocrine function [21-24] and together are potent stressors to the body. Coupled with operative trauma during surgery, these events will impact severely on the stress response. The stress indicators and markers elucidate the prospective direction of stressors. These aid in selection of anaesthetic agents, sutures and other corrective strategies that will elicit minimum stress and optimum reparative pathways. For instance, local/regional anesthesia for rumenotomy that helps reduce pain and desirable pathophysiological responses $[11,21,25]$ as well as the choice of suture materials that greatly dictates post-surgical tissue reactions and inflammatory processes. Therefore, there is a practical need for pragmatic combination of surgical sutures and local anesthetic that would evoke minimal post-surgical stress response and allow uncomplicated healing. Sutures and anesthetic agents putatively produce distinctive tissue reaction and inflammatory process. However, the indicators and biomarkers of surgical stress patterning following surgery in Sahel goats remain unclear. This study provides serum Hp profile of Sahel goats at five minutes post anesthetic induction of local anesthesia with lidocaine and bupivacaine after diazepam sedation. It also establishes $\mathrm{Hp}$ periodic profile peri- and post-rumenotomy responses of serum Hp, to chromic catgut (CCG) and polyglycolic acid (PGA) sutures in Sahel goats.

\section{Materials and Methods}

This study was conducted in Maiduguri, Borno state in the northeastern region of Nigeria. Maiduguri is located within latitude $11.15^{\circ} \mathrm{N}$ and longitude $30.05^{\circ} \mathrm{E}$ the Sudano-Savanna zone [26]. Fifteen apparently healthy Sahel goats aged $15.10 \pm 4.12$ months weighing $17.70 \pm 3.3 \mathrm{kgbw}$ were used for the study following due clearance from the Faculty of Veterinary Medicine Postgraduate Board, University of Maiduguri, Nigeria. The animals were procured from Maiduguri livestock market in Borno state, Nigeria. The goats were kept in the Department of Veterinary Surgery and Theriogenology pens and were fed groundnut husk, concentrates and water provided ad libitum. Animals were allowed to acclimatize for a period of two months before commencement of the experiment and special attention was given to their management. Using a random number generator (RNG $\left.{ }^{\circledast}\right)$ the groups $A, B$ and $\mathrm{C}$, were randomly allocated 5 goats per group with $\mathrm{A}$ and $\mathrm{B}$ as experimental groups while $\mathrm{C}$ as control. The goats were fasted for 12 and 6 hours for feed and water respectively. Blood samples $(5 \mathrm{mls})$ each were collected from jugular veins of all the 15 goats to establish base line data before commencement of treatments. The animals were placed on right lateral recumbency and the left paralumbar fossa was clipped and aseptically prepared with 4\% Chlorhexidine gluconate (Savlon ${ }^{\otimes}$ Vervaading deur, Johnson and Johnson (pty) Ltd, London). Prior to anaesthesia and surgery, a drip infusion line was instituted via the jugular vein for fluid therapy with $0.9 \%$ normal saline solution (Juhel ${ }^{\circledR}$, Fabrique par Juhel Nig. Ltd/ Awka, Anambra, Nigeria) as maintenance fluid. Diazepam, (SJG ${ }^{\oplus}$, Fazul Ellahie, Pvt Ltd, Karachi, Pakistan), $0.2 \mathrm{mg} / \mathrm{kg}$ IV was administered to experimental groups A and B for sedation. The goats in group A and B had $2 \%$ Lidocaine $\mathrm{HCl} 4 \mathrm{mg} / \mathrm{kg}$ (Lidocaine ${ }^{\circledR}$, Kwality Pharmaceuticals (P) Ltd.Nag Kalan, Majitha Road, Amritsar, INDIA) and $0.5 \%$ bupivacaine $1.5 \mathrm{mg} / \mathrm{kg}$ (Marcaine ${ }^{\bullet}$, Astrazeneca PLC, Ingi Itere Lisansi ile, Istanbul, Turkey) for an inverted L-block regional anaesthesia respectively on the left flank immediately after sedation. Five minutes after 
induction of local anesthesia, $5 \mathrm{~mL}$ of blood were drawn from the opposite jugular vein into a plain vacutainer tubes and kept at room temperature for 2 hours before centrifugation at $4000 \mathrm{xg}$ for 3 minutes in an electronic centrifuge (Centrifuge $800 \mathrm{~B}^{\circledR}$, Union Laboratories, England). Rumen skin clamp fixation technique of rumenotomy was employed and blood samples immediately post surgery at zero hour (38 \pm 6.0 minutes post surgery) was collected. Subsequently, blood were also collected at 5, 8, 24, 48 and 72 hours post surgery for evaluation of serum Hp.

The goat Hp ELISA (NeoBiolab ${ }^{\star}$, Serving Science Sharing Science, Cambridge, Massachusetts, USA) is a quantitative competitive immunoassay. The microtiter plate provided was coated with an Hp specific antibody. Standards or experimental samples were co-incubated in wells along with an Hp - HRP conjugate. Hp in standards/samples competes with Haptoglobin/Horse-RabbitPeroxidase (Hpt / HP - HRP) conjugate for binding to the plate bound antibody. Higher levels of Hpt/ HP from standard or samples lead to decreased Hp-HRP conjugate binding and reduced signal. The captured Hp - HRP is quantitatively detected by incubation with HRP substrates (Solution A and B). Binding of the Hp - HRP is visualized by production of colourimetric reaction products that were quantitatively measured by absorbance at $450 \mathrm{~nm}$ using a molecular microplate reader device (E max ${ }^{\oplus}$ precission microplate reader, USA).

The data obtained in this study were analyzed within groups using One Way Repeated Measures ANOVA with a Dunnett's Multiple Comparison Post Test and between groups with Two Way Repeated Measures ANOVA with Bonferroni post-test. Column statistics was used to determine $\mathrm{M} \pm \mathrm{SD}$ of the groups. Graphpad Prism Version 4.0, (2003) software was used for the data analysis. Analyses were considered significant at $\mathrm{P}<0.05$.

\section{Results}

The $\mathrm{Hp}$ values of goats in groups A, B and C are presented below (Table 1). The serum Hp values of goats in group C at baseline $1.34 \pm 0.91^{\mathrm{a}} \mathrm{mg} / \mathrm{mL}$ were compared with the baselines of group A $1.20 \pm 0.54 \mathrm{mg} / \mathrm{mL}$, and B $2.11 \pm 0.74 \mathrm{mg} / \mathrm{mL}$ and were not significantly different $(\mathrm{P}>0.05)$. This was also done for the values at the last day $(72 \mathrm{hrs})$ of the experiment for group $\mathrm{C} 1.02 \pm 1.46^{\mathrm{a}}$ $\mathrm{mg} / \mathrm{mL}$ to the baselines of groups $\mathrm{A}$ and $\mathrm{B}$ and were all not significantly different $(\mathrm{P}>0.05)$.

\begin{tabular}{|c|c|c|c|c|c|c|c|c|}
\hline & & & \multicolumn{5}{|c|}{ M \pm SD of Serum Haptoglobin $(\mathbf{m g} / \mathbf{m L})$ at Various Periods Post-Surgery } \\
\hline Group & Baseline & PAI (5mins) & $\mathbf{0 h r}$ & $\mathbf{5 h r}$ & $\mathbf{8 h r}$ & $\mathbf{2 4 h \mathbf { h r }}$ & $\mathbf{4 8 h r}$ & $\mathbf{7 2 h r}$ \\
\hline A & $1.20 \pm 0.54^{\mathrm{a}}$ & $1.02 \pm 0.39^{\mathrm{a}}$ & $1.10 \pm 0.10^{\mathrm{a}}$ & $2.02 \pm 0.39^{\mathrm{a}}$ & $2.89 \pm 1.28^{\mathrm{a}}$ & $4.38 \pm 2.53^{\mathrm{b}}$ & $4.05 \pm 0.76^{\mathrm{b}}$ & $6.23 \pm 1.82^{\mathrm{c}}$ \\
\hline B & $1.01 \pm 0.06^{\mathrm{a}}$ & $1.01 \pm 0.06^{\mathrm{a}}$ & $1.26 \pm 0.45^{\mathrm{a}}$ & $1.72 \pm 0.35^{\mathrm{a}}$ & $2.28 \pm 0.79^{\mathrm{a}}$ & $2.72 \pm 0.31^{\mathrm{a}}$ & $3.59 \pm 1.14^{\mathrm{b}}$ & $4.26 \pm 1.55^{\mathrm{c}}$ \\
\hline C & $1.34 \pm 0.91^{\mathrm{a}}$ & - & - & - & - & - & - & $1.02 \pm 1.46^{\mathrm{a}}$ \\
\hline
\end{tabular}

Values with different superscripts within a row are significantly different $(\mathrm{P}<0.05)$

Goats in group A and B had Diazepam-lidocaine with Chromic catgut sutures and Diazepam-bupivacaine with PGA sutures respectively for anaesthesia and rumen and abdominal muscle closure

Table 1: Mean Values of Haptoglobin (Hpt/Hp) $(\mathrm{mg} / \mathrm{mL})$ post anaesthetic induction (PAI) and different periods after surgery

This study revealed a significant difference $(\mathrm{P}<0.05)$ in the serum concentrations of $\mathrm{Hp}$ in goats at different time points when compared to these baseline data $1.20 \pm 0.54 \mathrm{mg} / \mathrm{mL}$, and $2.11 \pm 0.74 \mathrm{mg} / \mathrm{mL}$ for groups A and B respectively. The goats maintained the $\mathrm{Hp}$ baseline values at PAI and $0 \mathrm{hr}$ for group A and up to $5 \mathrm{hr}$ for group B. Significant difference $(\mathrm{P}<0.05)$ in the $\mathrm{M} \pm \mathrm{SD}$ were at 24,48 and $72 \mathrm{hrs}(4.38 \pm 2.53 \mathrm{mg} / \mathrm{mL}, 4.05 \pm 0.76 \mathrm{mg} / \mathrm{mL}$, and $6.23 \pm 1.82 \mathrm{mg} / \mathrm{mL})$ for group A and at $48 \mathrm{and} 72 \mathrm{hrs}(3.59 \pm 1.14 \mathrm{mg} / \mathrm{mL}$, $4.26 \pm 1.55 \mathrm{mg} / \mathrm{mL}$ ) for group B. The goats in group A and B showed peaked Hp values at $72 \mathrm{hrs} 6.23 \pm 1.82 \mathrm{mg} / \mathrm{mL}$ and $4.26 \pm 1.55$ $\mathrm{mg} / \mathrm{mL}$ respectively. The $\mathrm{Hp}$ values were significantly different $(\mathrm{P}<0.05)$ within groups at different time points. The values of the serum $\mathrm{Hp}$ in both groups did not change significantly $(\mathrm{P}>0.05)$ at five minutes post induction of anesthesia for both group $\mathrm{A}$ and $\mathrm{B}$.

\section{Discussion}

Haptoglobin (Hp) known as the second major acute phase protein (APP) of goats [27], has a normal range values of 0.39-1.26mg/ $\mathrm{mL}$ for goats but differ markedly among species [13]. The serum $\mathrm{Hp}$ concentrations in this experiment increased gradually for both groups A and B until significant at 24 hours and 48 hours respectively. The serum Hp concentrations for both groups rose steadily through 72 hours post surgery. Chromic catgut (CCG) for rumen and abdominal muscles closure in group A, caused tissue reaction and inflammation that significantly promoted rise in the Hp values that was earlier in onset of rise and highest in concentration among group A than group B that received PGA sutures. This finding indicates that CCG induces significant stress when used for surgeries in the goat. The serum Hp profile for group B also showed significant stress among the goats that received PGA sutures but these values were lower than for group A and the onset of the significant rise was at the second day of surgery while it was at day one for group A. Although this experiment showed Hp as suitable marker of surgical stress in the Sahel goat, the delay in the rise of the Hp values among the two groups confirmed earlier reports that Hp are not appreciable early markers of stress compared to serum amyloid A which is also a major positive acute phase protein (SAA) in the ruminants [27,28]. The serum Hp levels are usually peaked on the third day post inflammatory stimulus [27-29], further sampling beyond the third day (72hrs) could have better revealed Haptoglobin (Hp) patterning or profiling. The values of the serum Hp in both groups did not change significantly at five minutes post induction of anesthesia which may be attributed to the usual delay in rise of Hp as a late biomarker but this might require further studies to look at these anesthetic variables essentially different on the acute phase protein profile especially for haptoglobin. 


\section{Conclusion}

Evaluation of biomarker of stress Hp in the Sahel goat showed no significant stress at five minutes post induction of local anesthesia with lidocaine and bupivacaine post diazepam sedation. The suture in the experiment, CCG and PGA produced significant stress but was earlier in onset and highest in concentration among goats that had sutured rumen and abdominal muscles with CCG.

\section{Acknowledgements}

This Research was Funded by the TETFUND Research Fund.

\section{References}

1. Amstus HE (1980) Bovine Medicine and Surgery ( $2^{\text {nd }}$ Edn) Vol 2, American Veterinary Publications Inc, California, USA.

2. Dehghani SN, Ghadrdani AM (1995) Bovine Rumenotomy: Comparison of Four Surgical Techniques. Can Vet J 36: 693-7.

3. Edward RF (2002) Veterinary Surgery ( $7^{\text {th }}$ Edn) CBS Publishers and Distributors, India.

4. Holzheimer RG (2006) Adverse events of sutures: possible interactions of biomaterials? Eur J Med Res 10: 521-6.

5. Javed F, Al-Askar M, Almas K, Romanos GE, Al-Hezaimi K (2012) Tissue reactions to various suture materials used in oral surgical interventions. ISRN Dent 2012: 10.5402/2012/762095.

6. Jozsef B (2013) Experimental and Clinical Examination of Abdominal Wall Closure Complications (PhD Thesis), in Surgery, Universitas of Quinqueecclesiensis, Hungary.

7. Polly MT (1991) Farm Animal Practice: Anaesthesia in sheep and goats. In Practice 13: 32-6.

8. Caulkett N (2003) Anesthesia of Ruminants. Large Animal Veterinary Rounds 3: 1-6.

9. Tranquilli WJ, Thurmon JC, Grimm KA (2007) In: Lumb \& Jones Veterinary Anesthesia and Analgesia (4 ${ }^{\text {th }}$ Edn) Blackwell Publishing Professional, Iowa, USA.

10. Lyon L (2012) Local Anesthesia \& Analgesia, Western University of Health Sciences, California, USA.

11. Olaifa AK, Olatunji-Akioye AO, Agbaje LO (2009) Distal Paravertebral Nerve Block Effects on West African Dwarf Goat Haematology and Physiology. Israel J Veteri Med 64: 128-31.

12. Levy AP, Asleh R, Blum S, Levy NS, Miller-Lotan R, et al. (2010) Haptoglobin: basic and clinical aspects. Antioxid Redox Signal 12: 293-304.

13. Heller MC, Johns JL (2015) Acute phase proteins in healthy goats: establishment of reference intervals. J Vet Diagn Invest 27: 177-81.

14. Richter H (1974) Haptoglobin in Domestic Animals III Content in Plasma and Serum in Ruminants and Pigs under Various Physiological Conditions. Archive of Experimental Veterinarmed 28: 505-19.

15. Nagy O, Tóthová C, Nagyová V, Kováč G, Pošivák J (2014) Changes in the serum protein electrophoretic pattern in lambs during the first month of life. Acta Vet Brno 83: 187-93.

16. Piccione G, Stefania C, Claudia G, Irene V, Niutta PP, et al. (2009) Influence of age on profile of serum proteins in the calf. Acta Vet Beograd 59: 413-22.

17. Eckersall PD, Bell R (2010) Acute phase proteins: Biomarkers of infection and inflammation in veterinary medicine. Vet J 185: 23-7.

18. Petersen HH, Nielsen JP, Heegaard PM (2004) Application of acute phase protein measurements in veterinary clinical chemistry. Vet Res 35: 163-87.

19. Fisher AD, Crowe MA, O'Nualláin EM, Monaghan ML, Larkin JA, et al. (1997) Effects of cortisol on in vitro interferon-gamma production, acute-phase proteins, growth, and feed intake in a calf castration model. J Anim Sci 75: 1041-7.

20. Mckelvey D, Hollingshead KW (2003) Veterinary Anesthesia and Analgesia ( $3^{\text {rd }}$ Edn) Mosby Inc Publishers, USA.

21. Desborough JP (2000) The Stress Response to Surgery. Br J Anaesth 85: 109-17.

22. Burton D, Grainne N, George H (2004) Endocrine and Metabolic Response to Surgery. Continuing Education in Anesthesia, Critical Care \& Pain 4: 144-7.

23. Lisowska B, Rutkowska-Sak L, Maldyk P, Cwiek R (2007) Anaesthesiological problems in patients with rheumatoid arthritis undergoing orthopaedic surgeries. Clin Rheumatol 27: 553-6.

24. Lisowska B (2012) The Stress Response and Its Functional Implications in the Immune Response After Surgery in Patients with Chronic Inflammation Undergoing Arthroplasty. Recent Advances in Arthroplasty 15-34.

25. Oguntoye CO, Adetunji A (2009) Evaluation of Lignocaine/Bupivacaine Mixture For Central Neural Blockade in Goats. Israel J Vet Med 64: $122-7$.

26. Udo RK (1978) A Comprehensive Geography of West Africa. Holmes \& Meier Pub.

27. González FH, Tecles F, Martínez-Subiela S, Tvarijonaviciute A, Soler L, et al. (2008) Acute Phase Protein Response in Goats. J Vet Diagn Invest 20: 580-4.

28. Wells B, Innocent GT, Eckersall PD, McCulloch E, Nisbet AJ, et al. (2013) Two major ruminant acute phase proteins, haptoglobin and serum amyloid A, as serum biomarkers during active sheep scab infestation. Vet Res 44: 103.

29. Georgieva TM, Dishlyanova E, Jotov S (2011) Plasma Haptoglobin Concentrations after Normal Parturition and Caesarean Operation in Ewes with Dystocia (Preliminary Study). Revue de Medicine Veterinaire 162: 607-12. 


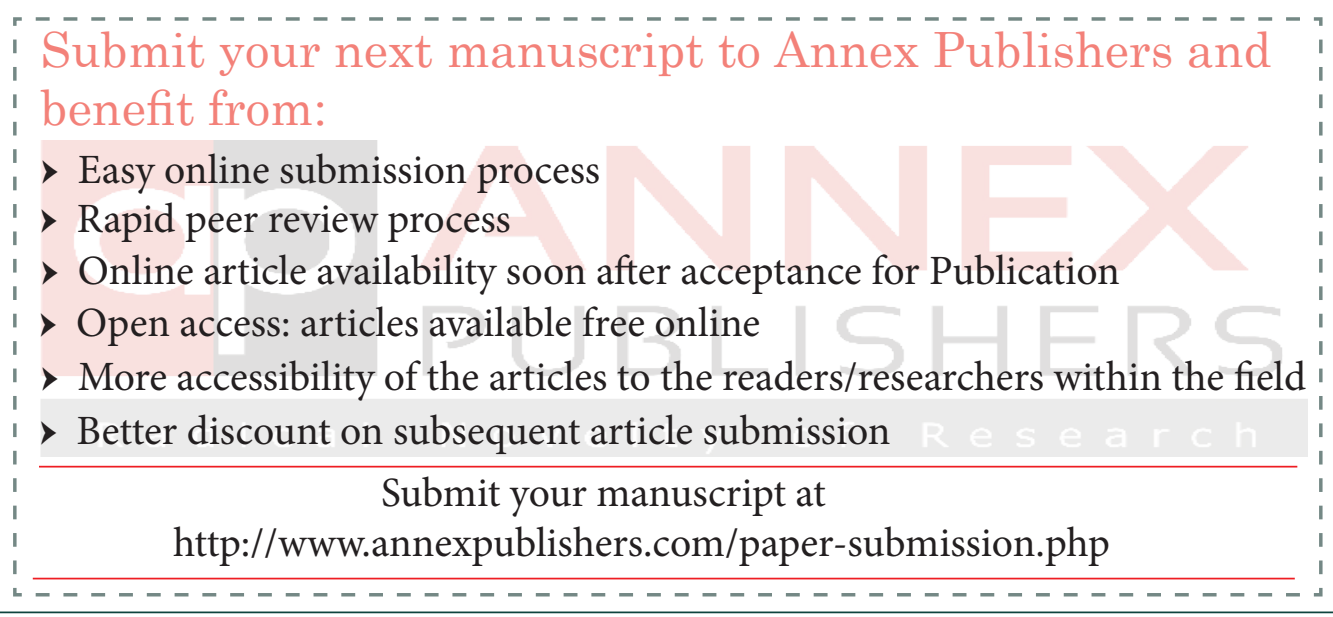

